\title{
EKSPLORASI GAYA BELAJAR MAHASISWA DAN KEMAMPUAN MENGKONSEPSI GAMBAR TEKNIK
}

\author{
Muhammad Rais* \\ ${ }^{I}$ Pendidikan Teknologi Pertanian, FT UNM \\ "raismisi@gmail.com
}

\begin{abstract}
ABSTRAK
Penelitian ini bertujuan untuk 1) mengidentifikasi karaktersitik gaya belajar mahasiswa yang memprogramkan mata kuliah Gambar Teknik, 2) menguji pengaruh gaya belajar terhadap kemampuan mengkonsepsi gambar teknik. Desain penelitian adalah pra eksperimen yang dilakukan terhadap 40 orang mahasiswa Jurusan Pendidikan Teknologi Pertanian angkatan 2016. Instrumen penelitian menggunakan Kolb Learning Style Inventory (KLSI) yang terdiri dari empat dimensi, yaitu gaya belajar diverging, converging, assimilator, dan accommodating. Hasil penelitian menunjukkan bahwa gaya belajar mahasiswa terdiri dari 4 (10\%) diverging, 12 (30\%) converging, 6 (15\%) assimilator, dan 18 (45\%) accommodating. Dengan demikian, gaya belajar didominasi oleh accommodating dan converging. Penelitian juga menunjukkan bahwa gaya belajar memiliki pengaruh yang signifikan dalam memberikan kemampuan mengkonsepsi gambar teknik.
\end{abstract}

Kata kunci : Gaya Belajar, Mengkonsepsi Gambar Teknik

\begin{abstract}
This study aims to 1) identify the characteristics of learning styles of students who programmed the drawings of Technical Drawing, 2) to examine the influence of learning styles on the ability to conceptualize engineering drawings. The research design is pre experiment conducted on 40 students of Agricultural Technology Education Department class of 2016. The research instrument uses Kolb Learning Style Inventory (KLSI) consisting of four dimensions, that is learning style of diverging, converging, assimilator, and accommodating. The results showed that student learning style consisted of $4(10 \%)$ diverging, 12 (30\%) converging, $6(15 \%)$ assimilator, and 18 (45\%) accommodating. Thus, learning styles are dominated by accommodating and converging. Research also shows that learning styles have a significant influence in providing the ability to conceptualize engineering drawings.
\end{abstract}

Keywords : Learning Style, conceptualize engineering drawings

\section{PENDAHULUAN}

Salah satu karakteristik belajar yang mempengaruhi cara mahasiswa dalam mengolah informasi termasuk dalam menggambar teknik adalah gaya belajar. Kemampuan mahasiswa terkait karakteristik belajar dalam menggambar teknik selain disebabkan karena bakat dan minat mahasiswa, gaya belajar diduga kuat memberi efek dalam mengkonstruksi pikiran mahasiswa untuk dikonversi kedalam bentuk perilaku belajar. Termasuk adalah perilaku belajar membaca gambar dan membuat garis-garis gambar.

Terkait gaya belajar, Kolb (1999) menyatakan terdapat empat kutub yang menggambarkan kecenderungan seseorang menggunakan gaya belajarnya ketika sedang melaksanakan proses belajar. Kecenderungan seseorang dalam menjalankan kebiasaan belajar menurut Kolb biasanya tidak dominan pada satu kutub tertentu, melainkan gabungan dari dua kutub atau lebih. 
Dalam menggambar teknik, memang sebaiknya gaya belajar yang dimiliki mahasiswa tidak hanya dominan pada satu jenis gaya belajar, melainkan bisa gabungan dari dua atau lebih kutub gaya belajar. Gaya belajar yang coba dieksplorasi dalam penelitian ini adalah gaya belajar Kolbs, yang membagi empat jenis gaya belajar yaitu: 1) kutub conrcete experience (CE) dan reflective observation $(R O)$ diwakili oleh gaya belajar diverging, 2) kutub reflective observation ( $R O)$ dan kutub abstract conceptualization (AC) diwakili oleh gaya belajar assimilating, 3) kutub abstract conceptualization $(A C)$ dan kutub active eksperimentation $(A E)$ diwakili oleh gaya belajar converging, dan 4) kutub active eksperimentation (AE) dan kutub conrcete experience $(C E)$ diwakili oleh gaya belajar accommodating (Kolb, 1999).

Kutub ini digambarkan sebagai berikut:

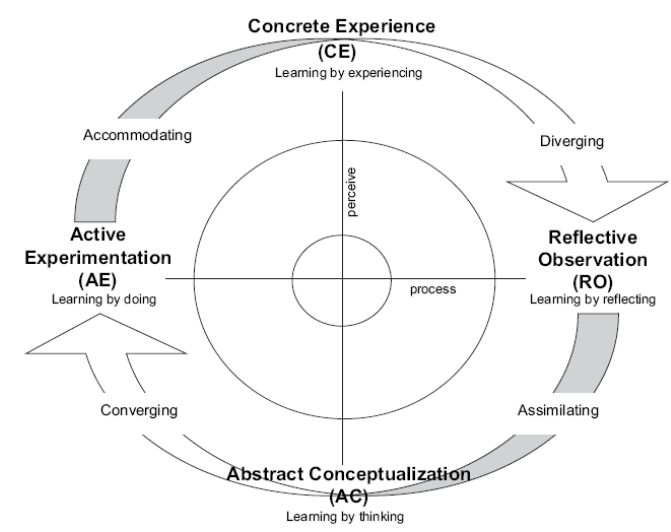

Gambar.1 Dimensi gaya belajar Kolb (1999).

Berdasarkan gambar di atas, Kolb (1999) menjelaskan setiap kutub sebagai berikut:

a. Kutub Perasaan/Feeling (Concrete

Experience)

Individu belajar melalui perasaan, dengan menekankan segi-segi pengalamann konkret, lebih mementingkan relasi dengan sesama dan sensitivitas terhadap perasaan orang lain. Dalam proses belajar, individu cenderung lebih terbuka dan mampu beradaptasi terhadap perubahan yang dihadapinya.

\section{b. Kutub Pemikiran/Thinking (Abstract Conceptualization)}

Individu belajar melalui pemikiran dan lebih terfokus pada analisis logis dari ide-ide, perencanaan sistematis, dan pemahaman intelektual dari situasi atau perkara yang dihadapi. Dalam proses belajar, individu akan mengandalkan perencanaan sistematis serta mengembangkan teori dan ide untuk menyelesaikan masalah yang dihadapinya.

\section{c. Kutub Pengamatan/Watching (Reflective Observation)}

Individu belajar melalui pengamatan, penekanannya mengamati sebelum menilai, menyimak suatu perkara dari berbagai perspektif, dan selalu menyimak makna dari hal-hal yang diamati. Dalam proses belajar, iIndividu akan menggunakan pikiran dan perasaannya untuk membentuk opini/pendapat.

\section{d. Kutub Tindakan/Doing (Active Experimentation)}

Individu belajar melalui tindakan, cenderung kuat dalam segi kemampuan melaksanakan tugas, berani mengambil resiko, dan mempengaruhi orang lain lewat perbuatannya. Dalam proses belajar, anak akan menghargai keberhasilannya dalam menyelesaikan pekerjaan, pengaruhnya pada orang lain, dan prestasinya.

$$
\text { Selanjutnya Kolb }
$$
mengembangkan empat fase siklus belajar tersebut dan mengidentifikasi empat gaya belajar berikut:

1. Converging: mahasiswa tipe ini adalah mereka yang mengandalkan konseptualisasi abstrak dan 
eksperimentasi aktif; mereka senang menemukan jawaban konkret dan bergerak dengan cepat untuk menemukan pemecahan masalah; mereka baik sekali dalam mendefinisikan masalah dan membuat keputusan; mereka tidak emosional; mereka lebih senang bekerja dengan ide-ide dari pada bekerja dengan orang lain.

2. Diverging: mahasiswa yang menggunakan pengalaman konkret dan pengamatan reflektif untuk memunculkan gagasan-gagasan; mereka bagus dalam brainstorming dan membuat alternatif; mereka paling senang berinteraksi dengan orang lain.

3. Assimilating: mahasiswa yang mengandalkan konseptualisasi abstrak dan pengamatan reflektif; mereka senang mengasimilasikan berbagai informasi dan menyusunnya kembali dengan logika yang tepat; mereka bagus dalam membuat perencanaan, mengembangkan teori dan menciptakan model, tetapi kurang tertarik dalam mengaplikasikan teori dalam kehidupan nyata, mereka belajar dengan baik dengan membaca, mendengarkan, mengamati, dan merenungkan informasi yang diperoleh.

4. Accommodating: mahasiswa yang belajar dengan baik dengan menggunakan pengalaman konkret dan eksperimentasi aktif; mereka sering menggunakan strategi trial-and-error daripada membaca instruksinya terlebih dahulu, atau intuisi untuk memecahkan masalah, mereka cenderung untuk mengambil resiko dan masuk ke dalam masalah tersebut, mereka pandai menyesuaikan diri dengan situasi baru.

Faktor gaya belajar menjadi salah satu faktor yang menarik untuk dikaji, karena variabel ini berkaitan dengan gaya kognitif seseorang dalam menggunakan dan mengoptimalkan strategi kognitif yang dimilikinya. Gaya belajar merupakan cara individu dalam menggunakan kemampuan, mempelajari dan mengolah suatu informasi, memperoleh pengetahuan dan keterampilan yang memberi sumbangan yang besar dalam pencapaian akademik (Winkel, 1989; Kolb, 1984; Sternberg \& Zhang, 2000; Lee, 2005; Santrock, 2007; Pritchard, 2008). Untuk dapat memperoleh hasil belajar yang maksimal, mahasiswa sedapat mungkin mengenal gaya belajar yang terdapat dalam dirinya.

Dalam penelitian ini, akan dikaji gaya belajar yang dikemukakan oleh Kolb (1984) yang lebih menekankan pada aktivitas (activiy-centered styles) yang membagi gaya belajar berdasarkan empat kutub kecenderungan, yaitu: 1) gaya belajar diverging, 2) gaya belajar assimilating, 3) gaya belajar converging, dan 4) gaya belajar accommodating. Keempat gaya belajar ini akan diukur dengan dengan menggunakan instrumen gaya belajar David A. Kolb (Kolb's Learning Style Inventory, KLSI).

\section{METODE PENELITIAN}

Penelitian ini menggunakan rancangan pra eksperimen. Penelitian pra experimental dengan versi desain the one-group pretest-posttest nonequivalent control group design (Tuckman, 1999). Penelitian ini hanya terdiri atas satu kelompok yang diukur gaya belajarnya menggunakan KLSI. Hasil pengukuran gaya belajar akan diperoleh empat jenis gaya belajar berdasarkan kecenderungan karakteristik mahasiswa.

Subjek dalam penelitian ini adalah mahasiswa program studi Pendidikan Teknologi Pertanian FT Universitas Negeri Makassar yang berada pada semester II tahun akademik 2016 berjumlah 40 orang. 


\section{Prosedur Penelitian}

Instrumen yang digunakan dalam penelitian ini dikelompokkan menjadi dua jenis, yaitu (1) instrumen untuk mengukur gaya belajar menggunakan KLSI dan (2) instrumen untuk mengukur kemampuan mengkonsepsi gambar teknik. Kedua instrumen ini berupa tes. Dasar pertimbangan adalah sebagai berikut: Instrumen pertama menggunakan instrumen gaya belajar KLSI (David A Kolb, 1999). Tes ini digunakan untuk mengukur kemampuan individu pebelajar dalam mengingat konsep berdasarkan empat kutub gaya belajar, yaitu Converging, Diverging, Assimilating, Accommodating. Instrumen untuk mengukur hasil belajar menggambar teknik berupa rubrik untuk mengukur kemampuan mengingat konsep gambar teknik. Data dikumpulkan melalui langkah-langkah sebagai berikut: 1) memberikan tes gaya belajar model KLSI, 2) memberikan pre-test, 3) melaksanakan pembelajaran dan 4) memberikan postest pada mahasiswa.

Analisis data dalam menguji hipotesis penelitian menggunakan analisis statistik parametrik, dengan teknik analisis Anova (analisys of variance) (Gall, 2003). Pengujian hipotesis nihil $\left(\mathrm{H}_{0}\right)$ dilakukan pada taraf signifikansi $5 \%$ atau $\alpha=0,05$. Untuk menguji hipotesis penelitian digunakan bantuan SPSS 21,00 for windows.

\section{HASIL DAN PEMBAHASAN}

\section{Deskripsi Gaya Belajar KLSI}

Data hasil pengukuran gaya belajar mahasiswa berdasarkan instrumen Kolb's Learning Style Inventory, ditunjukkan dalam tabel berikut:

Tabel 1. Gaya belajar Kolb

\begin{tabular}{lcc}
\hline \multicolumn{1}{c}{ Gaya Belajar } & Jumlah & $\%$ \\
\hline Diverging & 4 & 10 \\
Converging & 12 & 30 \\
\hline
\end{tabular}

\begin{tabular}{lcc} 
Assimilating & 6 & 15 \\
Accommodating & 18 & 45 \\
\hline & 40 & 100 \\
\hline
\end{tabular}

Berdasarkan Tabel 1, diperoleh gaya belajar mahasiswa adalah sebagai berikut: terdapat 4 orang atau sekitar 10 $\%$ yang memiliki gaya belajar diverging, sekitar 12 orang atau $30 \%$ mahasiswa memiliki gaya belajar converging, terdapat 6 orang atau sekitar $15 \%$ mahasiswa memiliki gaya belajar assimilating, dan sebanyak 18 orang atau sekitar $45 \%$ mahasiswa memiliki gaya belajar accommodating. Dengan demikian hasil analisis ini menunjukkan bahwa umumnya kecenderungan mahasiswa gaya belajar accommodating, kemudian gaya belajar converging, dilanjutkan dengan assimilating dan diverging.

Kecenderungan mahasiswa memiliki gaya belajar accommodating ditunjukkan dari perilaku belajar mahasiswa yang ketika menggambar teknik, seringkali menggunakan pengalaman konkret dan eksperimentasi aktif; mereka sering menggunakan strategi trial-and-error ketika menggambar teknik dibanding membaca instruksinya. Hal ini terjadi karena sebagian dari mahasiswa sudah mengerti teori gambar teknik untuk menarik garis gambar dan meletakkan angka ukuran yang tepat.

Kecenderungan kedua setelah gaya belajar accommodating adalah gaya belajar converging. Mahasiswa memiliki kecenderungan kedua yaiatu gaya belajar converging dimana mahasiswa lebih senang ketika menggambar teknik, berusaha menemukan jawaban konkret dan menggambar sendiri dengan cepat dan berupaya memecahkan sendiri masalah tanpa harus berdiskusi dan meminta konfirmasi dari teman mahasiswa lainnya. Kecenderungan kedua gaya 
belajar yang dimiliki oleh mahasiswa merupakan hasil dari pengalaman masa lalu ketika mahasiswa menemukan sendiri cara belajar yang sesuai dengan dirinya, hingga menjadi suatu kebiasaan yang bersifat menetap berdasarkan permasalahan belajar yang dihadapinya.

Data perbedaan kemampuan mengkonsepsi gambar teknik sebelum dan setelah pembelajaran dilakukan ditunjukkan dalam Tabel berikut:

Tabel 2: Nilai rata-rata Kemampuan Mengkonsepsi gambar teknik

\begin{tabular}{lc|c|c|c|c}
\hline & N & $\begin{array}{c}\text { Mini- } \\
\text { mum }\end{array}$ & $\begin{array}{c}\text { Max- } \\
\text { imum }\end{array}$ & Mean & SD \\
\hline Pretest & 40 & 20.00 & 45.00 & 30.63 & 5.873 \\
\hline Posttest & 40 & 62.00 & 90.00 & 80.48 & 6.345 \\
\hline Valid N (listwise) & 40 & & & & \\
\hline
\end{tabular}

Tabel 2 menunjukkan bahwa terdapat perbedaan nilai rata-rata pretest dan post-test kemampuan mengkonsepsi gambar teknik. Ada kecenderungan bahwa nilai rata-rata kemampuan mengkonsepsi gambar teknik meningkat sebesar 90 dari skor rata-rata pre-test yaitu 45 .

Untuk melihat skor rata-rata tingkat kemampuan mengkonsepsi gambar teknik terhadap keempat jenis gaya belajar ditunjukkan dalam gambar berikut:

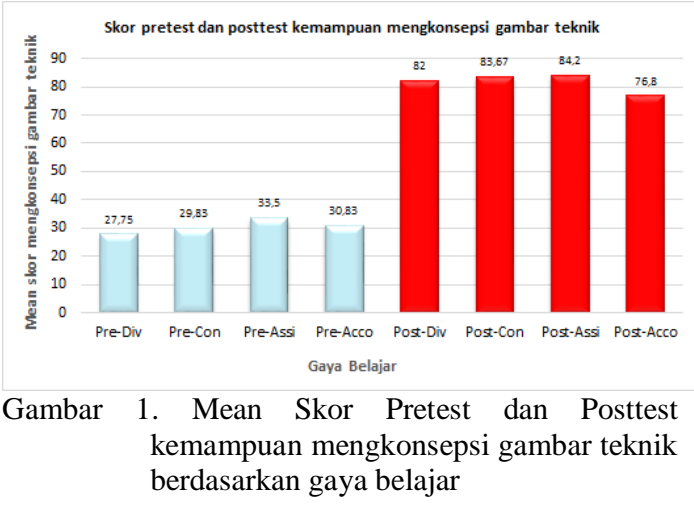

Keterangan:

Pre-Div = Mean skor pretest kemampuan mengkonsepsi gambar teknik pada mahasiswa yang memiliki gaya belajar diverging

Pre-Con $=$ Mean skor pretest kemampuan mengkonsepsi gambar teknik pada

mahasiswa yang memiliki gaya belajar converging

Pre-Assi = Mean skor pretest kemampuan mengkonsepsi gambar teknik pada mahasiswa yang memiliki gaya belajar assimilating

Pre-Acco $=$ Mean skor pretest kemampuan mengkonsepsi gambar teknik pada mahasiswa yang memiliki gaya belajar accommodating

Post-Div $=$ Mean skor posttest kemampuan mengkonsepsi gambar teknik pada mahasiswa yang memiliki gaya belajar diverging

Post-Con $=$ Mean skor posttest kemampuan mengkonsepsi gambar teknik pada mahasiswa yang memiliki gaya belajar converging

Post-Assi $=$ Mean skor posttest kemampuan mengkonsepsi gambar teknik pada mahasiswa yang memiliki gaya belajar assimilating

Post-Acco $=$ Mean skor posttest kemampuan mengkonsepsi gambar teknik pada mahasiswa yang memiliki gaya belajar accommodating

Gambar 1 menunjukkan bahwa mean skor pretest kemampuan mengkonsepsi gambar teknik paling tinggi dimiliki oleh mahasiswa yang bergaya belajar assimilating $=33,5$ dan accommodating $=30,83$. Hal yang skor posttest kemampuan mengkonsepsi gambar teknik paling tinggi juga dimiliki oleh mahasiswa yang bergaya belajar assimilating $=84,2$ dan converging $=83,67$. Gambar 1 juga menunjukkan bahwa skor rata-rata posttest kemampuan mengkonsepsi gambar teknik pada keempat gaya belajar lebih tinggi dibanding skor ratarata pretest. Hal ini ditunjukkan dalam Gambar 2 berikut:

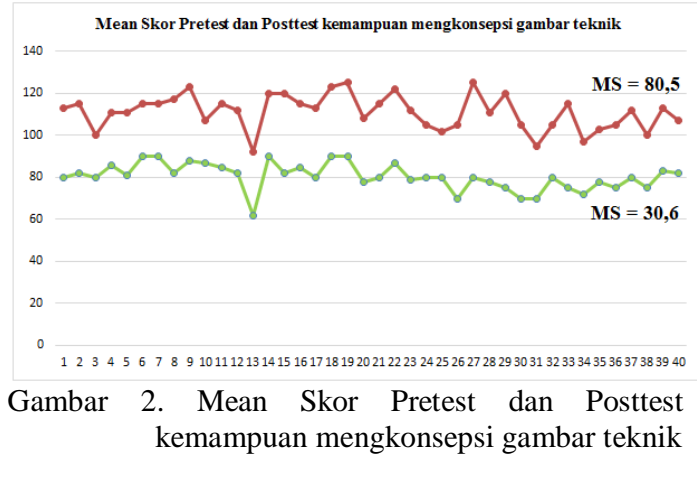


Gambar 2 menunjukkan bahwa mean skor posttest kemampuan mengkonsepsi gambar teknik lebih tinggi $\mathrm{MS}=80,5$ dibanding mean skor pretest dengan skor MS $=30,6$.

Hasil uji statistik disajikan dalam analisis varian (ANOVA) sebagai berikut:

Tabel 1. Hasil uji Anova gaya belajar dan kemampuan mengkonsepsi gambar teknik

\begin{tabular}{lc|c|c|c|c}
\multicolumn{7}{c}{ mengkonsepsi gambar teknik } \\
& $\begin{array}{c}\text { Sum of } \\
\text { Squares }\end{array}$ & df & $\begin{array}{c}\text { Mean } \\
\text { Square }\end{array}$ & F & Sig. \\
\hline $\begin{array}{l}\text { Between } \\
\text { Groups }\end{array}$ & 459.364 & 3 & 153.121 & 4.963 & .006 \\
\hline $\begin{array}{l}\text { Within } \\
\text { Groups }\end{array}$ & 1110.611 & 36 & 30.850 & & \\
\hline Total & 1569.975 & 39 & & & \\
\hline
\end{tabular}

Hasil analisis of varian seperti ditunjukkan dalam Tabel 1 memberikan penjelasan bahwa nilai $\mathrm{F}_{\text {hitung }}=4,963$ lebih besar dari $\mathrm{F}_{\text {tabel }}=2,86$ pada $\mathrm{df}=$ 40-4, dan nilai signifikansi $=0,006<$ 0,05 . Nilai $F_{\text {hitung }}$ yang $<F_{\text {tabel }}$ dan nilai signifikansi $0,006<0,05$ menujukkan bahwa terdapat perbedaan kemampuan mengkonsepsi gambar teknik diantara keempat gaya belajar mahasiswa.

Berdasarkan kajian terhadap berbagai penelitian yang dilakukan oleh para peneliti terkait pengaruh gaya belajar terhadap hasil belajar, umumnya ditemukan studi yang menunjukkan hubungan antara keduanya. Berikut disajikan beberapa hasil penelitian yang mendukung bahwa gaya belajar memiliki pengaruh terhadap perolehan hasil belajar, termasuk kemampuan mengkonsepsi gambar teknik, yaitu:

Temuan penelitian Mainemelis et al., (2002) dan Rutz, (2003) yang menemukan adanya dominasi prestasi belajar dalam menggambar desain interior pada mahasiswa yang bergaya belajar converging dibanding mahasiswa yang bergaya belajar diverging, assimilating, dan accommodating. Hal ini memungkinkan terjadi mengingat pemilihan subjek dari ketiga penelitian berasal dari jurusan ilmu desain arsitektur interior. Jurusan ini mengakomodasi gaya belajar converging dengan sifat dan karakteristik pebelajar yang menggunakan kemampuan praktikal dalam menemukan ide dan teori serta memliki kemampuan dalam memecahkan masalah dan bagus dalam membuat keputusan dan menemukan solusi dari permasalahan.

Penelitian yang dilakukan oleh Osman (2007) menunjukkan hubungan yang erat antara perolehan hasil belajar Desain Arsitektur Interior dengan gaya belajar diverging, converging, assimilating, dan accommodating. Dalam penelitian tersebut diperoleh rerata mahasiswa yang memiliki gaya belajar converging memiliki prestasi belajar Desain Arsitektur Interior yang lebih baik dibanding mahasiswa yang bergaya belajar diverging, assimilating, dan accommodating.

Hasil penelitian Bamidele (2008) menunjukkan bahwa rata-rata hasil belajar mahasiswa kedokteran Morehouse School of Medicine Atlanta yang bergaya belajar converging dan assimilating lebih tinggi dibanding mahasiswa yang bergaya belajar diverging dan accommodating. Hasil penelitian di atas, mengakomodasi dua jenis gaya belajar berdasarkan hasil pengukuran Kolb"s Learning Style Inventory, yaitu gaya belajar assimilating dan gaya belajar converging. Kedua jenis gaya belajar ini sama-sama dominan dimiliki oleh mahasiswa kedokteran dan mahasiswa teknik. Hal ini bukan sesuatu kebetulan karena modalitas belajar yang seharusnya menjadi kompetensi belajar mahasiswa pada kedua jurusan tersebut adalah selain teoretis, juga unggul dalam menemukan fungsi praktis, dari berbagai ide. Biasanya individu dengan gaya ini mempunyai kemampuan yang baik dalam pemecahan masalah dan pengambilaan keputusan, dan juga cenderung lebih menyukai tugas-tugas teknis dari pada masalah sosial.

Kajian secara teoretis dan temuantemuan hasil penelitian menunjukkan bahwa terdapat perbedaan karakteristik mahasiswa yang bergaya belajar diverging, converging, assimilating, dan 
accommodating. Gaya belajar converging dan assimilating cenderung menunjukkan hasil belajar yang lebih baik pada bidang ilmu tertentu seperti eksakta, teknik dan kedokteran. Sementara gaya belajar diverging, dan accommodating lebih akomodatif memberikan hasil belajar pada bidang ilmu sosial seperti psikologi, seni budaya, dan sejarah.

Dengan demikian kontribusi gaya belajar terhadap pembentukan kemampuan mengkonsepsi gambar teknik signifikan dalam memberi kontribusi. Berbedanya kemampuan mahasiswa dalam mengkonsepsi gambar teknik terjadi karena setiap mahasiswa sejak awal sudah memiliki cara dalam mengolah informasi dalam hal ini adalah gaya belajar. Menurut Rais (2017) perbedaan jenis gaya belajar akan memberikan perbedaan individu secara konseptual dalam mengelola pengetahuan yang dipelajarinya.

\section{KESIMPULAN}

Berdasarkan hasil analisis data dan kajian penelitian, pembahasan gaya belajar dan kemampuan mengkonsepsi gambar teknik memiliki keterkaitan yang erat. Dalam penelitian ini, diperoleh eksplorasi bahwa gaya belajar diverging, converging, assimilating, dan accommodating sebagai suatu gaya belajar berdasarkan kutub pengalaman belajar (experiental learning), telah mengkontribusi kemampuan mahasiswa dalam mengkonsepsi gambar teknik. Kemampuan mengkonsepsi ditunjukkan dengan kemampuan mahasiswa membuat garis ukuran, angka ukuran, dan membaca gambar teknik.

\section{UCAPAN TERIMAKASIH}

Penulis ucapkan banyak terimakasih kepada Rektor, Dekan, dan Ketua Program Studi Pendidikan Teknologi Pertanian atas dukungan biaya dan akses sarana hingga selesainya artikel penelitian ini. Terimakasih kepada panitia seminar nasional yang menyertakan artikel ini, semoga dapat memberi manfaat bagi pembaca.

\section{DAFTAR PUSTAKA}

Bamidele, A. A; Oluranti A; Marshaleen H.F; dan Chinedu, I. 2008. The Preferred Learning Style among Residents and Faculty Members of an Internal Medicine Residency Program. Journal of The National Medical Association, 100(2): 172-175.

Gall, M.D., Gall, J.P., \& Borg, W. R. 2003. Educational research: An Introduction. Seventh Edition. Boston: Pearson Education,Inc Kolb, D.A. 1984. Experiential Learning: Experience as The Source of Learning and Development. New Jersey: Prentice Hall, Inc.

Kolb, D.A. 1999. Learning Style Inventory. Version 3. Boston: Hay/McBer

Lee, W. Steven. 2005. Encyclopedia of School Psychology. United Kingdom: Sage Publications.

Mainemelis, C., Boyatzis, R., \& Kolb, D. A. 2002. Learning Styles and Adaptive Flexibility: Testing Experiential Learning Theory. Journal of Management Learning, 3(3): 25-33.

Osman, D. 2007. Learning Styles of Design Students and the Relationship of Academic Performance and Gender in Design Education. Learning and Instruction, 17(7) :345-359. 
Pritchard, Alan. 2008. Ways of Learning: Learning Theories and Learning Styles in the Classroom. New York: Routledge.

Rais, Muh. 2017. "Pengaruh Penggunaan Multimedia Presentasi Berbasis Prezi dan Gaya Belajar Terhadap Kemampuan Mengingat Konsep”. INA-Rxiv. September 21. osf.io/preprints/inarxiv/4dh5t.

Rutz, E. 2003. Learning Styles and Educational Performance Implications for Professional Development Programs. Learning and Instruction, 1(7) :34-39.

Santrock, W. John. 2007 Psikologi Pendidikan. Jakarta: Kencana Prenada Media Group.

Sternberg, J.R. \& Zhang, L.F. 2001. Perspectives on Thinking, Learning, and Cognitive Styles Educational Psychology Series. London: Lawrence Erlbaum Associates

Tuckman, W. B. 1999. Conducting Educational Research: Second Edition. USA: Harcourt Brace Jovanovich, Publisher.

Winkel, W.S. 1989. Psikologi pendidikan dan evaluasi belajar. Jakarta: Gramedia 